\title{
Strategi Pembelajaran Di Perguruan Tinggi Pada Masa Pandemi Covid-19
}

\author{
Ferawaty Puspitorini \\ Fakultas Ekonomi dan Bisnis; Universitas Bhayangkara Jakarta Raya; Jl. Raya \\ Perjuangan, Marga Mulya, Bekasi Utara, Jawa Barat 17121. Telp: 021-88955882, 889955883; \\ e-mail: fpuspitorini85@gmail.com \\ * Korespondensi: fpuspitorini85@gmail.com
}

\begin{abstract}
Begin the Year 2020, the world back appalled by the spread of the virus dangerous and deadly. The public call it as a corona virus. The emergence of the virus allegedly originated from the City of Wuhan, capital of Hubei Province, China. This Virus was first reported to WHO on 31 December 2019. This research is qualitative descriptive which describe the activities of online learning at the University of Bhayangkara Jakarta Raya after the enactment of the entire learning activities conducted at home with online mode. The subject consists of 3 students and 2 lecturers of Universitas Bhayangkara Jakarta Raya. Data collection using interviews. Based on the results of wawanccara learning activities with the online mode at the University of Bhayangkara Jakarta Raya have been effective with utilizing E-Learning applications Ubhara Jaya, Zoom and Google Classroom. Constraints in the implementation of online learning, namely the problem of internet connection less support.
\end{abstract}

Keywords: Online Learning, Pandemic, COVID-19

\begin{abstract}
Abstrak
Mengawali Tahun 2020, dunia kembali digemparkan dengan penyebaran virus berbahaya dan mematikan. Publik menyebutnya sebagai virus corona. Kemunculan virus tersebut ditengarai berawal dari Kota Wuhan, ibukota Provinsi Hubei, Tiongkok. Virus ini pertama kali dilaporkan ke WHO pada tanggal 31 Desember 2019. Penelitian ini merupakan deskriptif kualitatif yang mendeskripsikan kegiatan pembelajaran daring di Universitas Bhayangkara Jakarta Raya setelah ditetapkannya seluruh kegiatan pembelajaran dilaksanakan di rumah dengan mode daring. Subjek terdiri dari 3 mahasiswa dan 2 dosen Universitas Bhayangkara Jakarta Raya. Pengumpulan data menggunakan wawancara. Berdasarkan hasil wawanccara kegiatan pembelajaran dengan mode daring di Universitas Bhayangkara Jakarta Raya sudah efektif dengan memanfaatkan aplikasi E-Learning Ubhara Jaya, Zoom dan Google Classroom. Kendala dalam pelaksanaan pembelajaran daring yaitu masalah koneksi internet yang kurang mendukung.
\end{abstract}

Kata kunci: pembelajaran online, masa pandemi, COVID-19

\section{Pendahuluan}

Pandemi Covid-19 memaksa masyarakat dunia mendefinisikan makna hidup, tujuan pembelajaran dan hakikat kemanusiaan. Jika selama ini manusia-manusia dipaksa hidup dalam situasi serba cepat, pekerjaan tanpa henti, dan kejaran target pertumbuhan ekonomi dalam sistem kompetisi. Namun, persebaran virus Corona (Covid-19) yang menjadi krisis besar manusia modern, memaksa kita untuk sejenak bernafas, berhenti dari pusaran sistem, serta melihat kembali kehidupan, keluarga, dan lingkungan sosial dalam arti yang sebenarnya. 
Manusia dipaksa 'berhenti' dari rutinitasnya, untuk memaknai apa yang sebenarnya dicari dari kehidupan.

Persebaran virus Corona yang massif di berbagai negara, memaksa kita untuk melihat kenyataan bahwa dunia sedang berubah. Kita bisa melihat bagaimana perubahan-perubahan di bidang teknologi, ekonomi, politik hingga pendidikan di tengah krisis akibat Covid-19. Perubahan itu mengharuskan kita untuk bersiap diri, merespon dengan sikap dan tindakan sekaligus selalu belajar hal-hal baru. Indonesia tidak sendiri dalam mencari solusi bagi peserta didik agar tetap belajar dan terpenuhi hak pendidikannya. Sampai 1 April 2020, UNESCO mencatat setidaknya 1,5 milyar anak usia sekolah yang terdampak Covid 19 di 188 negara termasuk 60 jutaan diantaranya ada di negara kita.

Semua negara terdampak telah berupaya membuat kebijakan terbaiknya dalam menjaga kelanggengan layanan pendidkan. Indonesia juga menghadapi beberapa tantangan nyata yang harus segera dicarikan solusinya: (1) ketimpangan teknologi antara sekolah di kota besar dan daerah, (2) keterbatasan kompetensi tenaga pendidik dalam pemanfaatan aplikasi pembelajaran, (3) keterbatasan sumberdaya untuk pemanfaatan teknologi Pendidikan seperti internet dan kuota, (4) relasi tenaga pendidik-siswa-orang tua dalam pembelajaran daring yang belum integral.

Dalam mengatasi wabah COVID-19, pemerintah tidak melakukan karantina wilayah (lock down) tetapi menggunakan kebijakan Pembatasan Sosial Berskala Besar (PSBB). Dimulai dari ibukota Jakarta, kebijakan ini diikuti oleh wilayah lainnya. Kota Bekasi sebagai wilayah penyangga Jakarta segera menerapkan kebijakan PSBB mengingat wilayah ini berdekatan dengan dikhawatirkan terpengaruh dengan kota Jakarta yang merupakan zona merah dengan hampir separuh kasus COVID-19 ada di wilayah Jakarta. Untuk mengetahui efektifitas PSBB di kota Bekasi, penelitian ini mencoba menggunakan model Susceptible-Infected Recoverd (SIR) untuk mengukur laju penyebaran COVID-19. Hasilnya menunjukan adanya laju penurunan kasus terinfeksi dengan beta dan gamma beruturut-turut sebesar 0,071 dan 0,05 dan diprediksi akan berakhir di bulan Juni 2020. (Handayanto \& Herlawati, 2020).

Hal tersebut didukung oleh beberapa riset di seluruh dunia dalam memprediksi puncak sebaran COVID-19 yang beberapa negara sudah masuk dalam masa lonjakan kedua. Untuk wilayah Indonesia beberapa peneliti menggunakan pendekatan soft computing, seperti Support Vector Machine (SVM) regression, dengan beberapa kernel pilihan, antara lain radial basis function, linear and polynomial dengan akurasi yang beragam. Alat bantu dari Google (Google Interactive Notebook) sangat membantu dengan fasilitas kompiler dan servernya (Herlawati, 2020).

Pendidikan merupakan salah satu motor untuk meningkatkan kapasitas masyarakat, baik melalui pendidikan formal, informal maupun non-formal. Dalam meningkatkan sistem pendidikan, ada empat hal yang mesti dipenuhi sebelumnya yaitu sistem pendidikan yang komprehensif, guru yang berkarakter, peran pemerintah, dan kesadaran masyarakat. Mengacu pada pasal 3 UU No. 20 Tahun 2003, bahwa "Pendidikan nasional berfungsi mengembangkan 
kemampuan dan membentuk watak serta peradaban bangsa yang bermartabat..." (Widuroyekti, 2014). Dalam pelaksanaan pendidikan ada berbagai macam hambatan yang harus dilalui. Salah satunya ada hambatan yang terjadi pada masa sekarang ini yang berkaitan dengan bencana, yaitu wabah Corona Virus. Wabah tersebut sudah menjadi bencana di seluruh dunia.

Merebaknya kasus pandemi Corona Virus Disease 2019 (Covid-19) sejak Desember 2019 sampai saat ini mengharuskan semua proses kegiatan belajar mengajar bagi peserta didik untuk sementara waktu dilakukan di rumah. Hal itu perlu dilakukan guna meminimalisir kontak fisik secara massal sehingga dapat memutus mata rantai penyebaran virus tersebut. Untuk mengisi kegiatan belajar mengajar yang harus diselesaikan pada tahun pelajaran ini, pemerintah mengambil kebijakan pembelajaran dilakukan melalui pembelajaran jarak jauh dengan media daring (dalam jaringan), baik menggunakan ponsel, PC, atau laptop.

Pembelajaran ini sangat berbeda dengan pembelajaran konvensional yang terjadi di kampus. Dosen dan mahasiswa tidak berhadapan langsung, melainkan terjadi secara jarak jauh yang memungkinkan guru dan siswa berada pada tempat yang berbeda. Secara positif pembelajaran ini sangat membantu keberlangsungan pembelajaran di masa pandemi ini.

Media daring dirasa sangat efektif sebagai langkah solutif untuk mencegah penyebaran Covid-19 di lingkungan pendidikan. Tenaga pendidik dapat memberikan soal dan materi yang nantinya dikirim melalui ponsel atau laptop peserta didik atau orang tua. Kemudian peserta didik tinggal megerjakan tugas dari dosen. Hasil pekerjaan atau tugas tersebut dikirim kembali kepada dosen melalui platform yang sudah disediakan oleh pihak kampus ataupun dapat menggunakan platform lain yang sudah tersedia. Namun, merubah pola atau kebiasaan sangatlah sulit, dan merupakan hal wajar ketika terjadi perubahan yang sangat cepat dan tidak terduga.

Kebiasaan yang berubah secara signifikan ini misalnya, dosen dan mahasiswa sangat mengandalkan perangkat komputer dan jaringan internet, itu yang pertama. Kedua, Dosen dan mahasiswa harus mampu merubah gaya, strategi atau metode mengajar dan belajar. Ketiga, dosen dan mahasiswa harus mampu merubah gaya komunikasinya selama pembelajaran daring ini. Banyak guru yang tidak memperhatikan bagiaan yang ketiga ini, yaitu kurangnya pemahaman dan penerapan dosen dalam berkomunikasi dengan mahasiswanya. Dosen biasanya berkomunikasi satu atau dua arah di kampus, dengan bertatap muka secara secara langsung melakukan diskusi dan latihan secara bersama - sama.

Dosen akan lebih mudah memberikan pemaparan dan penjelasan suatu materi, sedangkan mahasiswa akan lebih mudah dalam memahami dan berdiskusi langsung kepada dosennya. Dengan kejadian pandemi ini, hal ini menjadi sangat sulit untuk tetap mempertahankan kebiasaan gaya komunikasi guru tersebut. Maka dari itu, perlu adanya perubahan gaya komunikasi guru selama atau saat pandemi Covid-19 ini. Komunikasi yang dipakai tentunya, yang bersifat jarak jauh dalam hal ini dikenal sebagai komunikasi daring.

Komunikasi ini, memungkinkan dosen sebagai komunikator dan mahasiswa sebagai komunikan melakukan komunikasi melalui jaringan internet atau dunia maya (cyberspace). 
Tujuannya ialah, bisa dikendalikan secara jarak jauh, efisiensi waktu jadi bisa dilakukan kapan saja dan dimana saja. Sangat mendukung kebijakan pemerintah dalam menaggulangi penyebaran pandemi ini. Di samping itu terdapat hal positif lainnya yang bisa didapatkan, seperti efisiensi biaya, sumber belajar yang luas, pengelolaan yang mudah, dan integrasi data.

Kampus Bhayangkara Jakarta Raya sudah menerapkan metode pembelajaran daring yang dilakukan dari bulan Maret 2020 sampai dengan akhir Semester Genap TA. 2019/2020. Dosen diberikan kebebasan dalam memilih atau menggunakan aplikasi untuk mendukung pembelajaran daring. Akan tetapi, untuk hal yang paling utama disarankan adalah menggunakan platform E-Learning yang sudah disediakan dari kampus. Alternative lain, dosen dapat menggunakan platform: Google Classroom, Edlink, Edmodo, Slack, Asana, Email, Whatsapp, Line, Skype, Youtube atau Zoom yang biasa digunakan di setiap fakultas.

Masing-masing dosen disarankan membuat kesepakatan dengan mahasiswa dalam penggunaan platform tersebut agar proses pembelajaran jarak jauh dapat berjalan dengan baik dan capaian mata kuliah (CMK) dapat terpenuhi. Untuk mekanisme penilaian hasil studi tetap mengikuti standar yang ada selama ini. Ada lima aspek penilaian, yaitu: Kehadiran, Tugas, Kuis, UTS dan UAS. Sedangkan untuk model penilaian UTS dan UAS ditentukan oleh masingmasing dosen. Dalam hal penilaian kehadiran, Universitas Bhayangkara Jakarta Raya menerapkan rentang waktu kehadiran perkuliahan mahasiswa adalah sesuai dengan jadwal perkuliahan dan dibuka sampai dengan enam hari sesudahnya.

Implementasi pembelajaran daring yang sudah berjalan beberapa bulan ini secara umum berjalan lancar. Kendati demikian, seiring perjalanan waktu sudah mencul banyak permasalahan. Di antaranya tugas dosen yang terlalu banyak sampai keluhan soal kuota dan jaringan internet. Tentu saja alangkah tidak bijak kalau serta merta menyalahkan para pendidik. Dalam situasi darurat, dosen harus bertindak cepat agar pembelajaran bisa berjalan efektif. Ponsel yang semula hanya sebagai media komunikasi, sekarang bermulti fungsi. Termasuk dalam memberikan materi dan tugas dalam durasi yang sangat pendek. Apresiasi layak diberikan kepada dosen, kampus dan peserta didik karena mereka bisa beradaptasi dengan cepat. Namun, seiring berjalannya waktu semua pihak perlu mengevaluasi pembelajaran daring tersebut agar tujuannya bisa tercapai secara optimal.

Banyaknya tugas dari dosen seringkali menjadi keluhan dalam pembelajaran daring. Beban belajar peserta didik tentunya harus diperhitungkan, terukur, baik secara materi maupun waktu. Tentunya perlu diingat bahwa pembelajaran di kelas tidak setiap saat diisi dengan tugas atau mengerjakan soal dalam jumlah banyak. Dosen bisa memberikan tugas mengamati, mencoba, dan menganalis, sehingga lebih menarik dan menantang. Meskipun pembelajaran jarak jauh, sapaan, respon, dan umpan balik atau penghargaan terhadap tugas yang dikerjakan merupakan hal yang tidak boleh dilupakan. Jangan sampai ada asumsi, peserta didik merasa diperdayai karena banyaknya tugas yang diberikan, tetapi tidak ada umpan balik dari dosen, seperti pekerjaan yang sudah dikerjakan maksimal tapi dosen tidak mengoreksi. 
Apresiasi kepada pekerjaan peserta didik perlu diberikan dosen agar tujuan pembelajaran bisa tercapai. Salah satu tujuan pembelajaran termasuk daring ini adalah pencapaian kompetensi peserta didik yang dikenal dengan $4 \mathrm{C}$, yaitu Critical thinking (berpikir kritis) yang mengarahkan peserta didik untuk untuk dapat menyelesaikan masalah (problem solving). Creativity thinking (berpikir kraetif) dapat dimaknai dosen bias mendampingi peserta didik yang memiliki kreativitas tinggi mampu berpikir dan melihat suatu masalah dari berbagai sisi atau perspektif. Pandemi Covid-19 kiranya bisa menjadi pintu masuk untuk mengubah pembelajaran tekstual menjadi kontekstual. Pembelajaran kontekstual merupakan konsep belajar yang mengaitkan antara materi pelajaran dalam kehidupan sehari-hari. Peserta didik diharapkan dapat menemukan dan mengembangkan pengetahuan dan keterampilan baru sesuai dengan pengetahuan yang mereka miliki. Dengan demikian, mereka akan lebih memahami dan lebih memaknai pengetahuannya. Dalam pelajaran ekonomi bisa diasah kemampuan membuat grafik perkembangan pandemi Covid-19 beserta prediksinya. Melalui pelajaran ilmu komunikasi bisa dilatih menganalisis dampak Covid-19 terhadap perkembangan seni pertunjukan dan alternatif solusinya. Dalam pelajaran Bahasa Inggris dilatih membuat essay (karya tulis) untuk penanggulangan pandemi Covid-19 atau membuat puisi, artikel, cerpen diharmonikan dengan situasi yang baru terjadi.

Dengan demikian, ketika peserta didik diasah kemampuannya untuk melihat dunia nyata dan memviralkan kepada publik melalui hasil analisisnya, sudah membuktikan nilai penguatan pendidikan karakter terutama nilai integritas sebagai aspek ungkapan bela rasa maupun empati kepada sesama. Selain masalah penerapan dan penggunaan aplikasi dalam pembelajaran jarak jauh. Ada satu masalah yang tidak dapat dilupakan dalam dunia pendidikan juga. Masalah tersebut terkait dengan tugas dosen yang harus melaksanakan Tri Dharma Perguruan Tinggi. Dengan adanya wabah Covid-19 ini, beberapa tugas Tri Dharma Perguruan tinggi menjadi terhambat. Misalnya, dalam pelaksanaan Penelitian dan Pengabdian Kepada Masyarakat.

Dosen harus lebih kreatif lagi dalam hal tersebut. Sebagai contoh, dalam bidang penelitian dapat dilakukan penelitian kualitatif yang mana tidak harus mencari data atau rsponden dari luar. Sehingga dosen tidak perlu kontak langsung atau datang kelapangan untuk mencari data. Dosen dapat membuat analisis dari berbagai sumber buku (bedah buku) untuk dijadikan penelitian. Sedangkan dalam bidang Pengabdian Kepada Masyarakat, dosen dapat melakukan pelatihan secara Online dengan menggunakan platform yang sudah dipilih atau dapat membuat sebuah karya yang disebut dengan Buku Abdimas yang tidak dipublikasikan. Buku tersebut dapat berbentuk Booklet yang berisi tentang tata cara melakukan sesuatu yang disesuaikan dengan bidang Ilmu masing-masing.

Di balik masalah dan keluhan tersebut, ternyata juga terdapat berbagai hikmah bagi pendidikan di Indonesia. Diantaranya, mahasiswa maupun dosen dapat menguasai teknologi untuk menunjang pembelajaran secara online ini. Di era disrupsi teknologi yang semakin canggih ini, dosen maupun mahasiswa dituntut agar memiliki kemampuan dalam bidang 
teknologi pembelajaran. Penguasaan mahasiswa maupun dosen terhadap teknologi pembelajaran yang sangat bervariasi, menjadi tantangan tersendiri bagi mereka. Dengan adanya kebijakan Belajar Dari Rumah (BDR) dan Work From Home (WFH), maka mampu memaksa dan mempercepat mereka untuk menguasai teknologi pembelajaran secara digital sebagai suatu kebutuhan bagi mereka. Tuntutan kebutuhan tersebut, membuat mereka dapat mengetahui media online yang dapat menunjang sebagai pengganti pembelajaran di kelas secara langsung, tanpa mengurangi kualitas materi pembelajaran dan target pencapaian dalam pembelajaran.

Setelah pendidik mampu menguasai berbagai sarana pembelajaran online, maka akan tercipta pemikiran mengenai metode dan model pembelajaran lebih bervariasi yang belum pernah dilakukan oleh pendidik. Misalnya, dosen membuat konten video kreatif sebagai bahan pengajaran. Dalam hal ini, dosen lebih persuasif karena membuat peserta didik semakin tertarik dengan materi yang diberikan oleh dosen melalui video kreatif tersebut. Peserta didik tentu akan dapat memahami apa yang dijelaskan oleh dosen melalui video kreatif yang dibuat oleh dosen tersebut. Sehingga dengan adanya penerapan model pembelajaran di rumah ini, membuat mahasiswa tidak merasa bosan dalam mengikuti pembelajaran secara online.

Adanya pandemi covid-19 juga memberikan hikmah yang lainnya. Pembelajaran yang dilakukan di rumah, dapat membuat orang tua lebih mudah dalam memonitoring atau mengawasi terhadap perkembangan belajar anak secara langsung. Orang tua lebih mudah dalam membimbing dan mengawasi belajar anak dirumah. Hal tersebut akan menimbulkan komunikasi yang lebih intensif dan akan menimbulkan hubungan kedekatan yang lebih erat antara anak dan orang tua. Orang tua dapat melakukan pembimbingan secara langsung kepada anak mengenai materi pembelajaran yang belum dimengerti oleh anak. Dimana sebenarnya orang tua adalah institusi pertama dalam pendidikan anak. Dalam kegiatan pembelajaran secara online yang diberikan oleh dosen, maka orang tua dapat memantau sejauh mana kompetensi dan kemampuan anaknya. Kemudian ketidakjelasan dari materi yang diberikan oleh dosen, membuat komunikasi antara orang tua dengan anak semakin terjalin dengan baik. Orang tua dapat membantu kesulitan materi yang dihadapi anak. Hikmah selanjutnya yaitu penggunaan media seperti handphone atau gadget, dapat dikontrol untuk kebutuhan belajar anak. Peran orang tua semakin diperlukan dalam melakukan pengawasan terhadap penggunaan gadget. Hal tersebut memberikan dampak yang positif bagi anak, dalam memanfaatkan teknologi untuk hal-hal yang bermanfaat. Anak cenderung akan menggunakan handphone untuk mengakses berbagai sumber pembelajaran dari tugas yang diberikan oleh dosen. Sehingga akan membuat anak menghindari penggunaan gadget pada hal-hal kurang bermanfaat atau negatif.

\section{Metode Penelitian}

Jenis penelitian ini adalah deskriptif kualitatif. Penelitian kualitatif adalah penelitian yang berlandaskan filsafat post positivism yang digunakan untuk meneliti kondisi objek yang 
alamiah dimana peneliti sebagai instrument kunci dan hasil penelitiannya lebih menekankan makna daripada generalisasi (Sugiyono, 2009). Penelitian deskriptif merupakan penelitian yang dilakukan untuk mendeskripsikan suatu variable, baik satu variable atau lebih (independen) tanpa membuat perbandingan, atau menghubungkan variable satu dengan variabel lainnya (Sugiyono, 2009). Di dalam penelitian ini, data yang dikumpulkan berupa kalimat dan penjabaran jawaban dari subjek yang dilakukan dengan wawancara. Pengambilan subjek menggunakan metode snowball throwing. Subjek terdiri dari 3 mahasiswa dan 2 dosen di Universitas Bhayangkara Jakarta Raya. Instrumen penelitian ini terdiri dari peneliti sebagai instrumen utama dengan instrument bantu wawancara. Data dalam penelitian ini berupa wawancara online melalui Whatsapp yang merupakan jawaban dari subjek merupakan deskripsi daro pengaruh COVID-19 terhadap perguruan tinggi Universitas Bhayangkara Jakarta Raya.

\section{Hasil dan Pembahasan}

Hasil penelitian dapat disimpulkan bahwa dampak COVID-19 terhadap kegiatan pembelajaran online di Universitas Bhayangkara Jakarta Raya oleh dosen 1 dalam Mata Kuliah Akuntansi sudah efektif dengan menggunakan aplikasi E-Learning Ubhara Jaya dan Zoom yang sudah beliau siapkan sejak awal. Pembelajaran dapat berjalan sebagai penyambung untuk menyelesaikan kegiatan pembelajaran yang belum selesai. Kendala yang dialami terdapat paada mahasiswa yaitu masalah koneksi internet dan kuota mahasiswa. Sedangkan pembelajaran online dosen 2 dalam Mata Kuliah Perjanjian Pernikahan, pembelajaran berjalan dengan lancar, perkuliahan dilaksanakan secara fleksibel. Aplikasi yang digunakan yaitu ELearning Ubhara Jaya dan Google Classroom sebagai tempat untuk mengirimkan materi dan mengabsen serta diskusi mahasiswa. Perkuliahan online ini dilakukan untuk menyelesaikan kegiatan pembelajaran yang belum terselesaikan. Pembelajaran melalui E-Learning Ubhara Jaya yang diampu dosen 2 menyenangkan karena mahasiswa menjadi aktif dan dosen 2 dapat berdiskusi satu persatu dengan para mahasiswa sehingga pembelajaran dapat dikatakan sudah efektif, meskipun terjadi kendala koneksi internet tetapi pembelajaran tetap berjalan dengan baik. Hasil wawancara mahasiswa dapat disimpulkan, pembelajaran online sebagai salah satu jalur penghubung pembelajaran yang belum usai menjadi salah satu solusi di Universitas Bhayangkara Jakarta Raya sebagai pengganti kegiatan pembelajaran tatap muka. Meskipun terdapat kendala, pembelajaran masih tetap berjalan dengan baik. Aplikasi yang digunakan untuk pembelajaran online yaitu E-Learning Ubhara Jaya, Zoom dan Google Classroom.

\section{Kesimpulan}

Walaupun pendidikan di Indonesia ikut terdampak adanya pandemi covid-19 ini, namun dibalik semua itu terdapat hikmah dan pelajaran yang dapat diambil. Adanya kebijakan pemerintah untuk melakukan pembelajaran jarak jauh melalui online, maka dapat memberikan manfaat yaitu meningkatkan kesadaran untuk menguasai kemajuan teknologi saat ini dan 
mengatasi permasalahan proses pendidikan di Indonesia. Pada akhirnya, perlu dipahami bahwa menetap sementara di tempat tinggal masing-masing sampai keadaaan membaik disertai dengan rasa kesadaran dan kesabaran menjadi langkah paling efektif. Golongan usia muda, baik mahasiswa, pekerja, maupun yang lainnya menjadi salah satu aktor paling penting dalam rangka memutus rantai penyebaran virus COVID-19. Sambil menunggu perkembangan situasi dan update kebijakan pemerintah, alangkah lebih baik kita semua sebagai golongan usia muda turut berpartisipasi membantu seluruh pihak dengan gerakan stay at home dan social distancing. Yakinlah bahwa situasi ini akan segera berlalu, jika kita sadar, kompak, dan paham mengenai tindakan yang kita lakukan. Indonesia menang melawan COVID-19.

\section{Daftar Pustaka}

Arnesti, N., \& Hamid, A. (2015). Penggunaan Media Pembelajaran Online - Offline Dan Komunikasi Interpersonal Terhadap Hasil Belajar Bahasa In-ggris. Jurnal Teknologi Informasi \& Komunikasi Da-lam Pendidikan, 2(1). https://doi.org/10.24114/ jtikp.v2i1.3284.

Basori, B. (2017). Efektifitas Komunikasi Pembelajaran Online Dengan Menggunakan Media ELearn-ing Pada Perkuliahan Body Otomotif. Jurnal II-miah Pendidikan Teknik Dan Kejuruan, 7(2), 39-45. https://doi.org/10.20961/iiptek.v7i2.12722.

Fakultas Kedokteran Universitas Lampung, \& Yuliana *). (2020). Corona virus diseases (COVID-19); Sebuah tinjauan literatur. Wellness and Healthy Magazine, 2(1), 187-192.

Gibbsons, M. (2002). The Self-Directed Learning Hand-book. John Wiley and Sons.

Handayanto, R. T., \& Herlawati, H. (2020). Efektifitas Pembatasan Sosial Berskala Besar (PSBB) Di Kota Bekasi Dalam Mengatasi COVID-19 Dengan Model Susceptible-InfectedRecovered (SIR). Jurnal Kajian Ilmiah, 20(2), 119-124. Https://Doi.Org/10.31599/Jki.V20i2.119

Herlawati, H. (2020). COVID-19 Spread Pattern Using Support Vector Regression. PIKSEL : Penelitian IImu Komputer Sistem Embedded And Logic, 8(1), 67-74. Https://Doi.Org/10.33558/Piksel.V8i1.2024

Hartanto, W. (2016). Penggunaan E-Learning sebagai Media Pembelajaran. Jurnal Pendidikan Ekonomi, 10(1), 1-18.

Kementerian Dalam Negeri. (2020). Pedoman Umum Menghadapi Pandemi COVID-19 Bagi Pemerin-tah Daerah. 1-206. https://doi.org/10.1017/ CBO9781107415324.004.

Maudiarti, Santi. (2018). Penerapan E-Learning di Perguruan Tinggi. Perspektif IImu Pendidikan, 32 (1), 53-68.

Nadeem, S. (2020). Coronavirus COVID-19: Available Free Literature Provided By Various Companies, Journals and Organizations Around the Literature Provided By Various Companies, Journals and Or-ganizations Around the World. March. https:// doi.org/10.5281/zenodo.3722904.

Riyana, C., \& Pd, M. (n.d.). Konsep Pembelajaran Online. 